\title{
Multi-location evaluation of yield component character and proximate analysis of cowpea grown in Lampung Province, Indonesia
}

\author{
ANUNG WAHYUDI ${ }^{1, \boldsymbol{v}}$, MUHAMAD SYUKUR ${ }^{2}$ \\ ${ }^{1}$ Politeknik Negeri Lampung. Jl. Soekarno Hatta No. 10, Rajabasa, Bandar Lampung 35144, Lampung, Indonesia. \\ Tel.:+62-721-703995, Fax.: +62-721-787309. ^email:anung@polinela.ac.id \\ ${ }^{2}$ Faculty of Agriculture, Institut Pertanian Bogor. Jl. Meranti, IPB University Campus Darmaga, Bogor 16630, West Java, Indonesia
}

Manuscript received: 4 September 2021. Revision accepted: 20 September 2021.

\begin{abstract}
Wahyudi A, Syukur M. 2021. Multi-location evaluation of yield component character and proximate analysis of cowpea grown in Lampung Province, Indonesia. Biodiversitas 22: 4246-4253. Cowpea has the potential to be developed in eastern Indonesia, especially Sulawesi, West Nusa Tenggara, East Nusa Tenggara, and Maluku with an altitude of less than $1000 \mathrm{~m}$ above sea level. Cowpea is also able to adapt to acid soils, making it possible to be developed in the dry acid soils of Sumatra and Kalimantan. To identify genotypes of high-yielding cowpea suitable for lowland areas, it is necessary to evaluate the multi-location of superior cowpea genotypes in different agroecology in the region. Multi-site evaluation trials of plant cultivars are of great importance given the obvious inconsistencies in genotype performance across different environments. This study used materials consisting of 4 varieties produced by the IPB University (Albina, Tampi, Uno, Arghavan) and 3 varieties from Balitkabi (KT-1, KT-7, and KT-9). This research is part of the preparation for the release of cowpea new varieties. The statistical analysis of the new varieties (Albina, Tampi, Uno, and Arghavan) compared with control (KT-1, KT-7, and KT-9) showed significant differences in seed productivity, carbohydrate content in old seeds, flowering, harvesting age in young pods and dry seeds. This result indicated that Albina, Tampi, Uno, and Arghavan varieties were potential for the release of new cowpea varieties, especially in the lowland areas.
\end{abstract}

Keywords: Characterization, low land, new variety, potential

Abbreviations: CV: Coeficient of Variance, DAP: Day After Pollination, LSD: Least Significant Different, KT: Kacang Tunggak or Indonesia cowpea name

\section{INTRODUCTION}

Cowpea (Vigna unguiculata [L.] Walp.) is a food crop and an important source of nutrients, as well as a major source of protein for millions of people in developing countries. In sub-Saharan Africa, smallholders are the main producers and consumers of cowpea, which is grown for its soft grain, leaves, and pods as food for human consumption, with crop residues used for animal feed or added back to the soil to improve fertility (Singh 2014). Cowpea belongs to the Fabaceae family with a chromosome number of $2 n=22$ and a genome size of 613 $\mathrm{Mb}$ (Arumuganathan and Earle 1991). Its genome has high collinearity with other summer legumes (Phaseoleae), including the common pea (Phaseolus vulgaris L.; Vasconcelos et al. 2015; Muñoz-Amatriaín et al. 2017). Highly fragmented draft assemblies and BAC sequence assemblies of IT97K-499-35 have previously been generated (Muñoz-Amatriaín et al. 2017). Although these resources have allowed advances in cowpea genetics (Yao et al. 2016; Carvalho et al. 2017; Misra et al. 2017; Huynh et al. 2018; Lo et al. 2018), they lack the proximity and completeness required for accurate genome annotation, detailed investigation of candidate genes or thorough genome comparisons. Here, we re-estimated the genome size of $V$. unguiculata and generated genome assembly using single-molecule real-time sequencing combined with optical and genetic mapping. Solanum lipocalin TILs and CHL protein can increased of yield of plants and environmental stresses (Wahyudi et al. 2018; Wahyudi et al. 2020).

Cowpea (Vigna unguiculata (L.) Walp.) is a member of the family Leguminoceae, and is often referred to as cowpea/southern pea/black bean/peas/red bean/crowders (United States), niebe/wake/ewa (United States). West Africa), and caupi (Brazil). Other names for cowpeas in Indonesia, especially in Java, are dadap beans, peanuts, otok beans, and tolo beans. The domestication of cowpea began in its native areas, namely West Africa and East Africa. The center of cowpea diversity other than Africa is South Asia (India). These beans can be used as sprouts, soy sauce, tempeh, tauco, cowpea (dhal), flour, and cheese (cheese analog) (Singh 2014). Cowpea tempeh contains protein, fat, fiber, with carbohydrates as the main component. Cowpea tempeh can lower blood pressure and glucose content and can weaken cancer-causing substances,

Cowpeas are tolerant of dry conditions, although water requirements at some stage must still be met. Cowpea adapts very well to both irrigated and dry land. Cowpea cultivation is generally carried out in rainfed dry land. Cowpeas can be grown in monoculture or intercropping with other food crops such as upland rice, corn, sorghum, cassava, and other legumes (komak, gude). To identify cowpea genotypes with high yields, it is necessary to 
evaluate multi-site genotypes of various superior cowpeas in different agro-ecologies in certain regions. Multi-site evaluation trials of plant cultivars are very important given the apparent inconsistencies in genotype performance in different environments (Ezeaku 2013). In addition, the increasing diversity of plants can use mutation (Molino 2017). The legume breeder at Politeknik Negeri Lampung (Polinela) collaborates with the IPB University breeder in the multilocation test or trial of cowpea in the Sumatra region (lowlands). The purpose of this study was to obtain information on the yield potential of a new variety of cowpea as a result of the research by a team of plant breeders from IPB University in lowland areas of Sumatra, especially Lampung province.

\section{MATERIALS AND METHODS}

\section{Materials}

This research was conducted using test and comparison varieties of cowpea originating from the Plant Breeding Education Laboratory, Department of Agronomy and Horticulture IPB as many as 4 test varieties and three comparison varieties from the Research Institute for Various Nuts and Bulbs (Balitkabi), Malang, East Java (Table 1). The other materials used in this research include plastic mulch, fertilizer (manure, Urea, SP-36, KCl, NPK Mutiara, Gandasil B), and agricultural lime. Field data collection equipment includes: measuring tools (ruler, meter), documentation tools (digital camera), plastic zipper, silica gel, container box, and scissors. Field equipment consisting of: hoe, shovel, and bucket/watering can.

\section{Experimental design}

The experiment was arranged in a randomized block design. The single factor consisted of four test varieties and three comparison varieties with three replications, each experimental unit consisted of two plots of beds (each bed consisted of 24 planting holes) with the following details: a plot will be observed until the harvest of young pods and onemore plot will be observed until the harvest of seeds. The experimental linear additive model used was:

\section{Data observation}

Observation and recording of characterization data were carried out using observation sheets and supported by personal apps, which were made to recap and document the images of each character. Observations were made for two adjacent beds in each experimental unit, namely the young pod harvest plot (plot i) and the dry seed harvest plot (plot ii). The observed variables refer to Kepmentan No.12 2019, IBPGR 1983, and UPOV 2009.

\section{Observations on young pod harvest plots (plot i)}

The quantitative character of the i tile: (i). Flowering age, determined when $50 \%$ of the plant population (e.g. 12 plants from 24 total plants) in the bed plot has flowered, (ii). Harvesting age of young pods is determined if $50 \%$ of the plant population (e.g. 12 plants out of 24 total plants) in the bed plots already has young pods with the fiber condition in the pods not dominant, the pods are still flexible, the color of the pods is still attractive, and suitable for consumption (fresh/young), (iii). Plant height $(\mathrm{cm})$, measured at ten plants in each plot chosen at random when the plants were $50 \%$ flowering. Plant height was measured from the soil surface to the highest plant height from the main stem (iv). Stem diameter (mm), measured at 10 plants in each randomly selected plot when the plants were $50 \%$ flowered. The stem diameter was measured by measuring the diameter of the stem $10 \mathrm{~cm}$ from the base of the stem (v). The number of branches, observed at the beginning of the flowering phase (the appearance of the first flowers in $50 \%$ of the plant population), (vi). The length of the main stem, the length of the main stem from the base of the stem to the point of branching, was observed at the beginning of the flowering phase (first flower appearance in $50 \%$ of the plant population), (vii). Leaf length, measured from leaf base to leaf tip, was observed at the beginning of the flowering phase (first flower appearance in $50 \%$ of the plant population), (viii). Leaf width, measured from the outermost side on both sides was observed at the beginning of the flowering phase (first flower appearance in $50 \%$ of the plant population), (ix). Petiole length, which is the length of the trifoliate petiole, is observed at the beginning of the flowering phase (first flower appearance in $50 \%$ of the plant population), (x). The number of flowers per plant, (xi). Weight per young pod was weighed on ten pods taken at random for each genotype in each replication (xii). The number of young pods per plot (fruit), were calculated for each plot in the whole harvest (xiii). m), measurements were taken by taking a sample of 10 pods in each randomly selected plot (xiv). Pod length $(\mathrm{cm})$, the measurement was carried out by measuring the length of the pod from the stalk of the pod to the tip of the pod by taking a sample of 10 pods in each randomly selected plot (xv). Weight of young pods per plot $(\mathrm{kg})$, calculated by: Weight of young pods per plot $\mathrm{kg}^{-1}=($ weight per young pod $\times$ number of pods per plot), (xvi). Productivity of young pods (ton ha-1), calculated by the formula: Productivity of young pods= (weight of young pods per plot $\mathrm{kg}^{-1} \times 1$ ton) $\times$ (land area 1 ha area 1 plot $5 \mathrm{~m}^{-2}$ ).

Tabel 1. Plant materials

\begin{tabular}{lll}
\hline Varieties & Source & Remark \\
\hline Albina & IPB & - \\
Uno & IPB & - \\
Tampi & IPB & - \\
Arghavan & IPB & - \\
KT-1 & Balitkabi & - \\
KT-7 & Balitkabi & $\begin{array}{l}\text { Tolerant to pest of pods, resitant } \\
\text { toCAMV, fairly high yield, harverst (68- }\end{array}$ \\
& & $\begin{array}{l}\text { 70 DAP) } \\
\text { Tolerant to pest of pods, fairly high } \\
\text { KT-9 }\end{array}$ \\
& Balitk, harverst (68-70 DAP)
\end{tabular}


Qualitative character of plot i: (i). Anthocyanin staining, observed at the base of the stem at the seedling phase 7 DAP (Days After Planting), (ii). Leaf color intensity, observed at the beginning of the flowering phase (first flower appearance in $50 \%$ of the plant population), (iii). Flower color, observed in 3 parts of the flower, namely the standard, wing, and boat of each genotype taken at random (iv). Flower bud color, observed in 3 flower buds of each genotype taken at random (v). The color of the stamens and the color of the pistil were observed on three flowers of each genotype which were taken at random (vi). Terminal leaf shape was observed on 3 leaves of each genotype which were taken randomly (Hastate, Sub-hastate, Globose, Sub-globose (vii). Stem color observations were made by observing the color of the stems of 3 cowpea plants randomly in each genotype when the plants were $50 \%$ flowered (viii). The color of the young pods was observed in 3 young pods of each genotype which were taken at random (ix). Anthocyanin staining on the pods, the presence or absence of a red to purple color formed in the pods.

\section{Observation on dry seed harvest plot (plot ii)}

The quantitative character of the plot ii: (i). Seed harvest age, Seed harvesting age is determined when $50 \%$ of the plant population (eg. 12 plants out of 24 total plants) in the bed plots have ripe pods (ii). Weight per dry pod, calculations were carried out at harvest by weighing 10 pods taken at random for each genotype in each replication (iii). Seed weight per pod was weighed on one pod of 10 dry pods taken at random for each genotype in each replication (iv). Weight per seed, the weight per seed of 10 dry pods was taken randomly for each genotype in each replication (v). Seed length, was observed in dry seeds (vi). Seed width, was observed for dry seeds (vii). The number of dry pods per plot, was calculated for each plot for the entire harvest (viii). Weight of dry pods per plot $(\mathrm{kg})$, calculated by the formula: Dry pod weight per plot = Weight per dry pod $\times$ number of dry pods per plot (ix). Seed weight per plot $(\mathrm{kg})$, calculated by: Seed weight per plot $=$ Weight per seed $\times$ number of seeds per pod $\times$ number of dry pods per plot (x). The weight of 100 seeds was calculated by taking 100 seeds randomly for 8 measurements (weighed) in each replication, then averaged (xi). Seed productivity (ton $\mathrm{ha}^{-1}$ ), calculated by the formula: Productivity $=\left(\right.$ weight of seeds per plot $\mathrm{kg}^{-1} \times 1$ ton $) \times($ area of 1 ha area of 1 plot of $5 \mathrm{~m}^{-2}$ ).
Qualitative character of plot ii: (i). Seed shape (kidney, ovoid, crowder, globose, rhomboid). (ii). The color of old pods was observed in 3 dry pods of each genotype which were taken randomly (iii). The surface texture of the pods, observed when the pods are ripe (iv). The color intensity of the pods was observed when the pods were ripe with anthocyanin staining parameters/not weak, moderate, to strong (v). Base color of seeds (white, brown, beige, black) (vi). Seed secondary color (reddish brown, black).

\section{Proximate analysis}

Proximate analysis was performed using standard AOAC methods, and mineral contents were determined using atomic absorption spectrometry.

\section{RESULTS AND DISCUSSION}

\section{The quantitative character}

Field evaluation of advanced breeding materials across multiple environments is one way of identifying highperforming genotypes. Parameters such as days to maturity, 100 seed weight, and grain yield are very important in selecting cowpea genotypes for release. In this study, the statistical analysis of seeds productivity (Table 2) and seed yield (Table 5) of the varieties from IPB University (Albina, Tampi, Uno, Argavan) compared with control from BALITKABI (KT-1, KT-7, and KT-9) showed significant differences. Seed productivity and seed yield (number of dry pods) of cowpea varieties from IPB University are higher than varieties from BALITKABI.

Cowpea production is constrained by various field pests, disease infestation, amount of rain, drought, and photoperiod, and this varies from one agroecology to another. To identify highyielding and well adapted cowpea genotypes, multilocation evaluation of a large number of diverse improved cowpea genotypes must be carried out within the different agro-ecologies of the region. Multi-site evaluation trials of plant cultivars are very important because plant genotypes will be determined in different environments. Genotype analysis based on the environment can be carried out to help identify the genotypes of highyielding and stable plant cultivars for the test environment (Asio et al. 2009; Horn et al. 2018; Sousa et al. 2018). These different environmental conditions resulting in different yield responses of cowpea genotypes can be attributed to the genotype's interaction with the environment (Odeseye et al. 2018). The flowering age of cowpea varieties from 35-47 days (Table 3 ).

Table 2. Quantitative data of productivity components

\begin{tabular}{|c|c|c|c|c|c|c|c|c|c|}
\hline Variety & $\begin{array}{l}\text { Weight per } \\
\text { young } \\
\text { pods }(\mathrm{g})\end{array}$ & $\begin{array}{l}\text { Weight } \\
\text { per dry } \\
\text { pods (g) }\end{array}$ & $\begin{array}{l}\text { Weight of } \\
\text { seeds per } \\
\text { pods (g) }\end{array}$ & $\begin{array}{l}\text { Weight } \\
\text { young pods } \\
\text { per plot (kg) }\end{array}$ & $\begin{array}{l}\text { Weight dry } \\
\text { pods per } \\
\text { plot (kg) }\end{array}$ & $\begin{array}{l}\text { Weight of } \\
\text { seed per } \\
\text { plot (kg) }\end{array}$ & $\begin{array}{l}\text { Weight of } \\
100 \text { seeds }(g)\end{array}$ & $\begin{array}{l}\text { Productivity } \\
\text { of young pods } \\
\text { (t/ha) }\end{array}$ & $\begin{array}{l}\text { Productivity } \\
\text { of seeds }\end{array}$ \\
\hline Albina & $26.76 \mathrm{ab}$ & $2.74 \mathrm{bc}$ & $27.43 \mathrm{bc}$ & $2.61 \mathrm{ab}$ & 2.30 & $1.60 \mathrm{~b} \mathrm{c}$ & $13.60 \mathrm{bc}$ & $4.56 \mathrm{~b}$ & $3.21 \mathrm{~b}$ \\
\hline Uno & $37.23 \mathrm{bc}$ & $2.63 \mathrm{bc}$ & $26.66 \mathrm{bc}$ & $4.66 \mathrm{c}$ & 2.51 & $1.98 \mathrm{c}$ & $13.05 \mathrm{ab}$ & $4.43 \mathrm{ab}$ & $3.97 \mathrm{~b}$ \\
\hline Arghafan & $47.30 \mathrm{c}$ & $2.91 \mathrm{c}$ & $29.10 \mathrm{c}$ & $3.94 \mathrm{bc}$ & 2.28 & $1.6 \mathrm{~b} \mathrm{c}$ & $13.18 \mathrm{abc}$ & $8.16 \mathrm{c}$ & $4.23 \mathrm{~b}$ \\
\hline $\mathrm{KT}-1$ & $15.40 \mathrm{a}$ & $2.89 \mathrm{c}$ & $28.93 \mathrm{c}$ & $1.77 \mathrm{a}$ & 1.56 & $0.83 \mathrm{a}$ & $13.02 \mathrm{ab}$ & $2.62 \mathrm{ab}$ & $1.61 \mathrm{a}$ \\
\hline KT-7 & $12.33 \mathrm{a}$ & $2.71 \mathrm{bc}$ & $28.50 \mathrm{c}$ & $2.01 \mathrm{a}$ & 1.40 & $1.05 \mathrm{ab}$ & $12.13 \mathrm{a}$ & $2.40 \mathrm{ab}$ & $2.11 \mathrm{a}$ \\
\hline KT-9 & $14.10 \mathrm{a}$ & $2.25 \mathrm{a}$ & $23.60 \mathrm{a}$ & $1.35 \mathrm{a}$ & 1.20 & $0.61 \mathrm{a}$ & $12.54 \mathrm{ab}$ & $2.39 \mathrm{ab}$ & $1.70 \mathrm{a}$ \\
\hline LSD $5 \%$ & 18.08 & 0.26 & 2.63 & 1.64 & Ns & 0.71 & 1.14 & 2.15 & 1.04 \\
\hline $\mathrm{CV}(\%)$ & 36.66 & 7.31 & 5.45 & 31.69 & 32.87 & 29.00 & 4.86 & 25.88 & 19.41 \\
\hline
\end{tabular}

Note: The numbers followed by the same letter in the same column are not significantly different according to the 5\% LSD test 
Table 3. Quantitative data of flowering until harvesting time

\begin{tabular}{|c|c|c|c|c|c|c|c|c|c|c|c|}
\hline Variety & $\begin{array}{l}\text { No. of } \\
\text { pods }\end{array}$ & $\begin{array}{l}\text { No. of } \\
\text { flowers }\end{array}$ & $\begin{array}{l}\text { No. of young } \\
\text { pods per plot }\end{array}$ & $\begin{array}{l}\text { Young pods } \\
\text { length }(\mathbf{c m})\end{array}$ & $\begin{array}{l}\text { Young pods } \\
\text { diameter }(\mathrm{cm})\end{array}$ & $\begin{array}{l}\text { Petiole } \\
\text { lenght }(\mathrm{cm})\end{array}$ & $\begin{array}{l}\text { Seed } \\
\text { length } \\
(\mathbf{m m})\end{array}$ & $\begin{array}{l}\text { Seed } \\
\text { width } \\
(\mathbf{m m}) \\
\end{array}$ & $\begin{array}{l}\text { Flowering age } \\
\text { (dap) }\end{array}$ & $\begin{array}{l}\text { Age per } \\
\text { young pods } \\
\text { (dap) }\end{array}$ & $\begin{array}{l}\text { Dry seed } \\
\text { harvesting age } \\
\text { (dap) }\end{array}$ \\
\hline Albina & $15.26 \mathrm{ab}$ & $11.00 \mathrm{a}$ & $989.33 \mathrm{~b}$ & $15.86 \mathrm{a}$ & $0.53 \mathrm{a}$ & $12.41 \mathrm{~b}$ & $8.14 \mathrm{bc}$ & $5.39 \mathrm{a}$ & $38.00 \mathrm{ab}$ & $48.00 \mathrm{a}$ & $56.00 \mathrm{a}$ \\
\hline Tampi & $14.43 \mathrm{a}$ & $25.00 \mathrm{c}$ & $1007.66 \mathrm{~b}$ & $20.02 \mathrm{~d}$ & $0.65 \mathrm{~b}$ & $13.05 \mathrm{~b}$ & $8.87 \mathrm{~cd}$ & $5.13 \mathrm{a}$ & $35.00 \mathrm{a}$ & $45.00 \mathrm{a}$ & $54.00 \mathrm{a}$ \\
\hline Uno & $14.80 \mathrm{ab}$ & $13.00 \mathrm{ab}$ & $948.66 \mathrm{~b}$ & $15.55 \mathrm{a}$ & $0.50 \mathrm{a}$ & $13.68 \mathrm{bc}$ & $8.92 \mathrm{~cd}$ & $5.40 \mathrm{a}$ & $38.00 \mathrm{ab}$ & $44.00 \mathrm{a}$ & $56.00 \mathrm{a}$ \\
\hline Arghafan & $14.83 \mathrm{ab}$ & $19.00 \mathrm{abc}$ & $919.66 \mathrm{~b}$ & $19.70 \mathrm{~cd}$ & $0.63 \mathrm{~b}$ & $9.01 \mathrm{a}$ & $9.13 \mathrm{~d}$ & $5.40 \mathrm{a}$ & $36.00 \mathrm{a}$ & $46.00 \mathrm{a}$ & $62.00 \mathrm{~b}$ \\
\hline KT-1 & $17.16 \mathrm{~d}$ & $25.00 \mathrm{c}$ & $448.33 \mathrm{a}$ & $18.62 b c$ & $0.69 \mathrm{~b}$ & $18.85 \mathrm{a}$ & $7.00 \mathrm{a}$ & $6.19 \mathrm{~b}$ & $42.00 \mathrm{bc}$ & $52.00 \mathrm{~b}$ & $66.00 \mathrm{~b}$ \\
\hline KT-7 & $16.30 \mathrm{~cd}$ & $25.00 \mathrm{c}$ & $447.00 \mathrm{a}$ & $15.66 \mathrm{a}$ & $0.70 \mathrm{~b}$ & $15.98 \mathrm{~d}$ & $7.80 \mathrm{ab}$ & $6.30 \mathrm{~b}$ & $45.00 \mathrm{~cd}$ & $55.00 \mathrm{bc}$ & $66.00 \mathrm{~b}$ \\
\hline KT-9 & $15.46 \mathrm{bc}$ & $23.00 \mathrm{bc}$ & $415.33 \mathrm{a}$ & $17.94 \mathrm{~b}$ & $0.70 \mathrm{~b}$ & $15.15 \mathrm{~cd}$ & $7.40 \mathrm{ab}$ & $6.00 \mathrm{~b}$ & $47.00 \mathrm{~d}$ & $57.00 \mathrm{c}$ & $66.00 \mathrm{~b}$ \\
\hline LSD $5 \%$ & 1.01 & 10.01 & 23.68 & 1.28 & 0.08 & 1.82 & 0.85 & 0.36 & 4.05 & 3.88 & 4.46 \\
\hline CV $(\%)$ & 3.66 & 29.30 & 17.00 & 4.07 & 6.90 & 7.30 & 5.91 & 3.44 & 5.66 & 4.39 & 4.30 \\
\hline
\end{tabular}

Note: The numbers followed by the same letter in the same column are not significantly different according to the 5\% LSD test 
Tampi and Arghavan varieties are earlier flowerings compared to others. Three varieties from BALITKABI (KT-1, KT-7, and KT-9) were slow flowering compared to varieties from IPB University (Albina, Tampi, Uno, and Arghavan) (Table 3). In cowpea breeding, large quantities of seeds are required. During the hybridization process, the beginning of flowering of mature cowpea lines was 30 days after planting, while the mature lines flowered 40 days after planting. On the other hand, naturally pollinated cowpea flowers produce an average of 10 seeds depending on the variety, while hand-pollinated flowers produce an average of 5 seeds. To avoid waiting for the plant to reach the vegetative stage before flowering, asexual reproduction is another method for the hybridization process (Frankel and Galun 2012). The data of dry seeds harvesting age shown that control varieties (BALITKABI) were slower than IPB University varieties. The result of the experiment showed that IPB varieties (Albina, Tampi, Uno, Arghavan) were earlier flowering (36-38 DAP) and dry seeds harvesting age (56-62 DAP) compared with control varieties (Table 3). The result of seeds in peanuts (Neya et al. 2017) showed that the weight of 100 seeds has been significant at specific combining ability (SCA).

The statistical data of plants performance, such as the plant height, the number of branches, the leaf length, and the plant lenght were not significantly different (Table 4). Control varieties (KT-1, KT-7, and KT-9) were higher for the stem diameter and the leaf wide (Table 4).

The result of qualitative character in leaf color intensity showed that Albina, Tampi, and Arghavan had light green color intensity, whereas Uno, KT-1, KT-7, and KT-9 had dark green color intensity (Figure 1). The result of flower color, observed in 3 parts of the flower, namely the standard, wing, and boat of each genotype taken at random. At the standard part, the flower color showed that Albina, Tampi, and Uno had a white color, Arghavan, KT-1, KT-7, and KT-9 had the white purple color a flower. At the wing part, the flower color showed that only Albina, which did not show purple color, the other variety had purple color. At the boat part, the flower color showed that almost all varieties had white color (Figure 1). The purple color is an indication that the flower of cowpea has anthocyanin content. The color of the young pods was observed in 3 young pods of each genotype which were taken at random. The result of the young pod's color showed that Arghavan variety had strong purple intensity compared to others. Anthocyanin staining on the pods, the presence or absence of a red to purple color formed in the pods, that mean Arghavan variety had high anthocyanin content in young pods. The result of seeds showed that Albina, Tampi, Uno, and Arghavan had kidney seed shapes. The seed shape of KT-1, KT-7, and KT-9 were ovoid shapes. The seeds of Albina and Tampi were present white milk color. The only Arghavan had a dark brown color intensity of seeds. The color of the seed coat may be a good indicator of the accumulation of flavonoids in cowpea. Cowpeas with dark seed coats, especially black varieties, contain high levels of anthocyanins, while red seed varieties contain high levels of flavonols. Red, black, light brown, and golden brown varieties were also found to contain high concentrations of flavan-3-olds. The level of individual phenolic compounds depends on the variety rather than on the phenotype (Ojwang 2012). Characters that are influenced by additive gene action and have high diversity allow them to be selected in the F2 generation using the genealogical selection method (Purnamasari 2019).

\section{Proximate analysis}

Proximate analysis was performed using standard AOAC methods, and mineral contents were determined using atomic absorption spectrometry. The findings for the proximate composition of the cowpea leaf are presented in Table 6 and Figure 2. The moisture content of the leaf showed that KT-7 variety $(87.38 \%)$ is higher than other varieties, but lower in carbohydrate content. KT-9 variety was higher carbohydrate content $(8.53 \%)$ compared to other variety. The protein content of the leaf showed that Albina variety $(4.35 \%)$ was higher than other varieties. The lipid content of the leaf showed that the Tampi variety (6.05) was higher compared to others (Table 6 and Figure 2).

Table 4. Quantitative data of plants performance

\begin{tabular}{lcccccc}
\hline \multicolumn{1}{c}{ Variety } & $\begin{array}{c}\text { Plant height } \\
(\mathbf{c m})\end{array}$ & $\begin{array}{c}\text { Stem diameter } \\
(\mathbf{c m})\end{array}$ & No. of branches & $\begin{array}{c}\text { Leaf length } \\
(\mathbf{c m})\end{array}$ & $\begin{array}{c}\text { Leaf width } \\
(\mathbf{c m})\end{array}$ & $\begin{array}{c}\text { Plant length } \\
(\mathbf{c m})\end{array}$ \\
\hline Albina & 66.25 & $1.15 \mathrm{c}$ & 7.80 & 14.16 & $10.37 \mathrm{c}$ & 66.25 \\
Tampi & 64.58 & $1.04 \mathrm{~b}$ & 7.27 & 12.18 & $9.42 \mathrm{ab}$ & 64.58 \\
Uno & 68.86 & $1.02 \mathrm{~b}$ & 7.73 & 14.56 & $9.06 \mathrm{ab}$ & 68.86 \\
Arghafan & 75.64 & $0.89 \mathrm{a}$ & 7.20 & 12.15 & $10.04 \mathrm{bc}$ & 75.64 \\
KT-1 & 70.54 & $1.84 \mathrm{~d}$ & 7.20 & 14.61 & $11.86 \mathrm{~d}$ & 70.54 \\
KT-7 & 69.10 & $1.80 \mathrm{~d}$ & 6.50 & 15.30 & $12.28 \mathrm{~d}$ & 69.10 \\
KT-9 & 61.90 & $1.86 \mathrm{~d}$ & 7.30 & 13.30 & $11.61 \mathrm{~d}$ & 61.90 \\
& & & & & & \\
LSD 5\% & $\mathrm{ns}$ & 0.09 & ns & Ns & 0.94 & $\mathrm{~ns}$ \\
CV $(\%)$ & 6.85 & 3.75 & 9.85 & 13.88 & 4.94 & 6.85 \\
\hline
\end{tabular}

Note: The numbers followed by the same letter in the same column are not significantly different according to the 5\% LSD test 

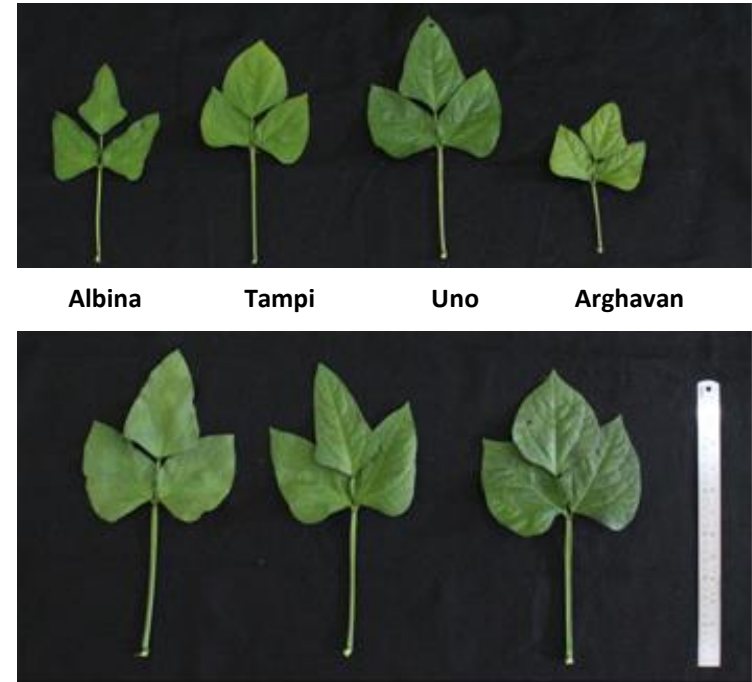

KT-1

KT-7
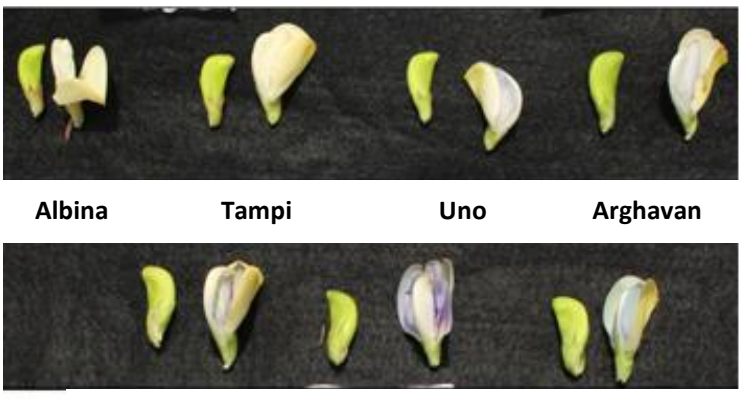

KT-1

KT-7

KT-9
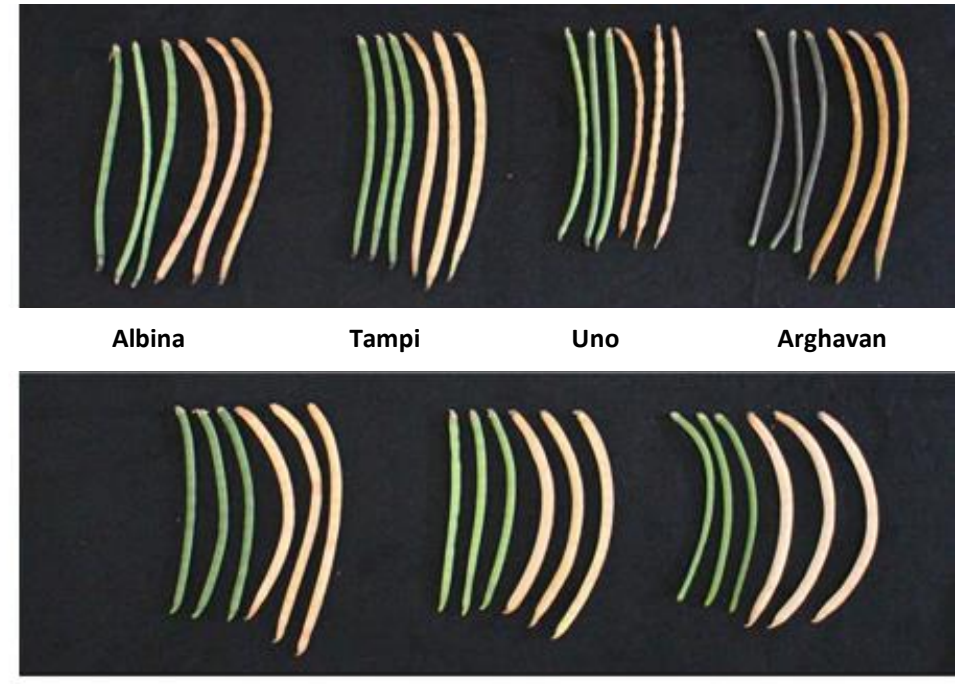

KT-1

KT-7

KT-9
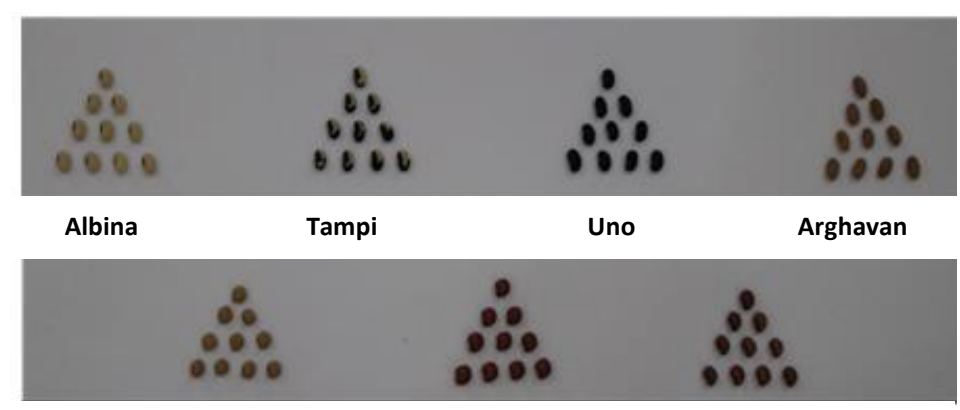

KT-1

KT-7

KT-9

Figure 1. Qualitative character of leaf, flower, pod, and seeds

$\mathbf{A}_{\substack{10000 \\ \text { 1000 }}}$

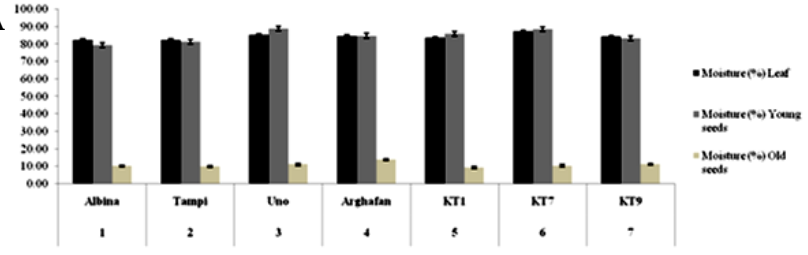

B

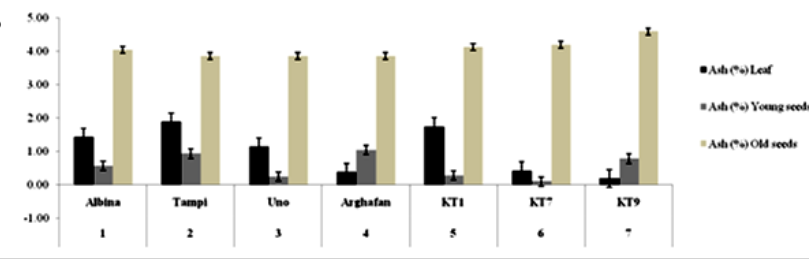

C

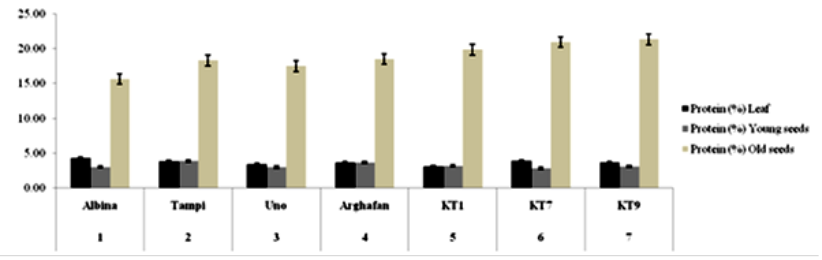

D

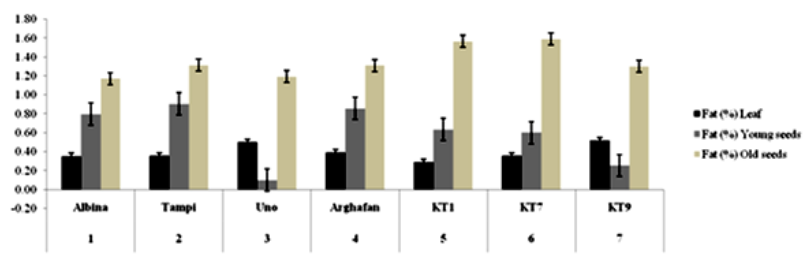

E
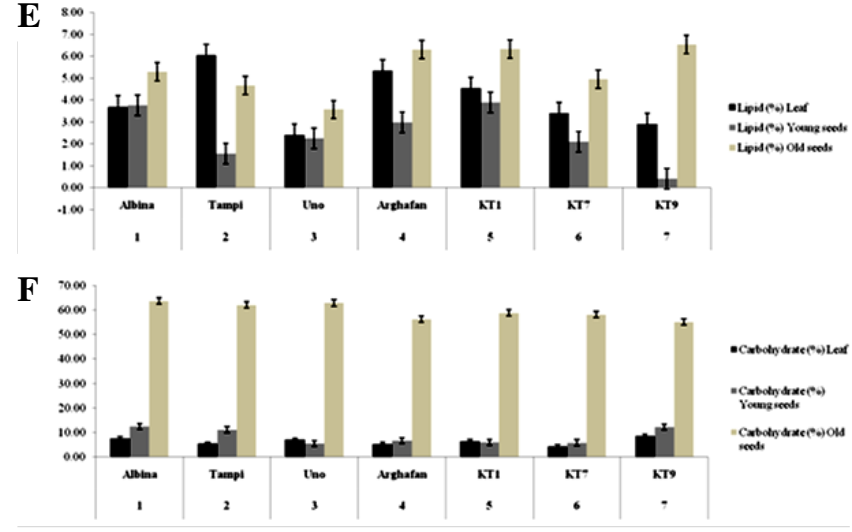

Figure 2. Proximate analysis data on leaf, young seeds, and old seeds. A. Moisture content, B. Ash content, C. Protein content, D. Fat content, E. Lipid content, F. Carbohydrate content. Proximate analysis was performed using standard AOAC methods and mineral contents were determined using atomic absorption spectrometry. 
Table 5. Quantitative data of seeds yield

\begin{tabular}{|c|c|c|c|c|c|}
\hline \multirow{2}{*}{ Variety } & \multicolumn{3}{|c|}{ No. of dry pods } & \multicolumn{2}{|c|}{ Seed weight } \\
\hline & Harvest to 1 & Harvest to 2 & Harvest to 3 & $1(\mathrm{~g})$ & $2(\mathrm{~g})$ \\
\hline Albina & $283.66 \mathrm{ab}$ & $388.66 \mathrm{c}$ & $270.00 \mathrm{~b}$ & 0.13 & 1.03 \\
\hline Tampi & $451.50 \mathrm{c}$ & $444.83 \mathrm{c}$ & $187.00 \mathrm{ab}$ & 0.14 & 0.93 \\
\hline Uno & $269.16 \mathrm{ab}$ & $497.00 \mathrm{c}$ & $259.00 \mathrm{~b}$ & 0.14 & 0.87 \\
\hline Arghafan & $409.66 \mathrm{bc}$ & $366.66 \mathrm{bc}$ & $102.16 \mathrm{a}$ & 0.14 & 1.10 \\
\hline KT-1 & $189.33 \mathrm{a}$ & $211.66 \mathrm{ab}$ & $152.33 \mathrm{a}$ & 0.15 & 1.08 \\
\hline KT-7 & $173.66 \mathrm{a}$ & $200.33 \mathrm{ab}$ & $116.83 \mathrm{a}$ & 0.10 & 1.00 \\
\hline KT-9 & $152.66 \mathrm{a}$ & $196.00 \mathrm{a}$ & $104.00 \mathrm{a}$ & 0.10 & 0.80 \\
\hline LSD 5\% & 152.72 & 170.62 & 98.47 & Ns & Ns \\
\hline CV $(\%)$ & 31.14 & 29.12 & 32.52 & 9.82 & 20.33 \\
\hline
\end{tabular}

Tabel 6. Proximate data analysis of leaf

\begin{tabular}{lcccccc}
\hline \multirow{2}{*}{ Sample } & Moisture & Ash & Protein & Fat & Lipid $\begin{array}{c}\text { Carbo- } \\
\text { hydrate }\end{array}$ \\
\cline { 2 - 7 } & \multicolumn{5}{c}{$(\mathbf{\% )}$} \\
\hline Albina & 82.42 & 1.42 & 4.35 & 0.35 & 3.69 & 7.76 \\
Tampi & 82.36 & 1.88 & 3.85 & 0.36 & 6.05 & 5.50 \\
Uno & 85.40 & 1.13 & 3.44 & 0.50 & 2.40 & 7.12 \\
Arghafan & 84.80 & 0.38 & 3.68 & 0.39 & 5.35 & 5.40 \\
KT-1 & 83.81 & 1.74 & 3.06 & 0.29 & 4.54 & 6.57 \\
KT-7 & 87.38 & 0.41 & 3.94 & 0.36 & 3.39 & 4.51 \\
KT-9 & 84.20 & 0.18 & 3.66 & 0.52 & 2.91 & 8.53 \\
\hline
\end{tabular}

Tabel 7. Proximate data analysis of young seeds

\begin{tabular}{lcccccc}
\hline \multirow{2}{*}{ Sample } & Moisture & Ash & Protein & Fat & Lipid & $\begin{array}{c}\text { Carbo- } \\
\text { hydrate }\end{array}$ \\
\cline { 2 - 7 } & \multicolumn{5}{c}{$(\boldsymbol{\%})$} \\
\hline Albina & 79.40 & 0.56 & 3.04 & 0.80 & 3.77 & 12.43 \\
Tampi & 81.52 & 0.93 & 3.92 & 0.91 & 1.56 & 11.17 \\
Uno & 88.92 & 0.24 & 2.99 & 0.10 & 2.26 & 5.48 \\
Arghafan & 84.79 & 1.04 & 3.69 & 0.86 & 2.99 & 6.64 \\
KT-1 & 86.02 & 0.28 & 3.20 & 0.64 & 3.90 & 5.97 \\
KT-7 & 88.52 & 0.10 & 2.83 & 0.60 & 2.09 & 5.86 \\
KT-9 & 83.21 & 0.78 & 3.12 & 0.26 & 0.40 & 12.24 \\
\hline
\end{tabular}

Tabel 8. Proximate data analysis of old seeds

\begin{tabular}{lcccccc}
\hline \multirow{2}{*}{ Sample } & Moisture & Ash & Protein & Fat & Lipid $\begin{array}{c}\text { Carbo- } \\
\text { hydrate }\end{array}$ \\
\cline { 2 - 7 } & \multicolumn{5}{c}{$(\boldsymbol{\%})$} \\
\hline Albina & 10.07 & 4.03 & 15.64 & 1.17 & 5.29 & 63.80 \\
Tampi & 9.80 & 3.85 & 18.31 & 1.32 & 4.66 & 62.06 \\
Uno & 10.96 & 3.85 & 17.47 & 1.19 & 3.57 & 62.96 \\
Arghafan & 13.75 & 3.85 & 18.49 & 1.31 & 6.31 & 56.29 \\
KT-1 & 9.18 & 4.12 & 19.85 & 1.57 & 6.33 & 58.95 \\
KT-7 & 10.20 & 4.19 & 20.94 & 1.59 & 4.96 & 58.12 \\
KT-9 & 11.09 & 4.59 & 21.33 & 1.30 & 6.55 & 55.14 \\
\hline
\end{tabular}

The potential of cowpea seeds to be processed into value-added products would be influenced by their physical and chemical properties. Physical properties such as seed coat texture affect hydration characteristics, while chemical composition affects cooking properties of seeds. The proportions of chemical components such as carbohydrate and protein influence seed cooking time.

Results in Table 7 and Table 8 show the proximate composition in young seeds and old seeds. Albina variety had higher carbohydrate content in the young seeds $(12.43 \%)$ and the old seeds $(63.80 \%)$ compared to other varieties. Climatic and agronomic practices vary widely in mineral content as represented by the ash value. The protein and carbohydrate contents contributed $25 \%$ of total variance in proximate components having the highest correlations with the 2 and 3 CDFs (Henshaw 2008). These components are important in determining the nutritive quality and processing quality of cowpea seeds. The content of fat was the least discriminating variable. The low fat content in cowpea is an advantage during processing to flour, since unlike other legumes such as soybean. The result of the protein content was interesting. The result in Table 7 showed that Tampi and Arghavan varieties had higher protein contents in young seeds $(3.92 \%$ and $3.69 \%$ ). Contrary, the results in Table 8 showed that KT-1, KT-7, and KT-9 had high protein contents in old seeds $(19.85 \% ; 20.94$; and $21.33 \%)$.

To summary, this research is part of the preparation for the release of cowpea new varieties. The statistical analysis of the new varieties (Albina, Tampi, Uno, and Arghavan) compared with control (KT-1, KT-7, and KT-9) showed significant differences in seed productivity, carbohydrate content in old seeds, flowering, harvesting age in young pods and dry seeds. This result indicated that Albina, Tampi, Uno, and Arghavan varieties were potential for the release of new cowpea varieties, especially in the lowland areas.

\section{ACKNOWLEDGEMENTS}

The author would like to thank the Ministry of Education, Culture, Research and Technology for funding this research through an Applied Research grant with Contract nos. 2051/IT3.L1/PN/2021 in 2021 and Polinela which has facilitated the research area (Seed Teaching Farm) and facilitated proximate analysis. 


\section{REFERENCES}

Arumuganathan K, Earle ED. 1991. Nuclear DNA content of some important plant species. Plant Mol Biol Rep 9 (3): 208-218. DOI: 10.1007/BF02672069

Asio MT, Osiru DSO, Adipala E. 2009. Multilocational evaluation of selected local and improved cow pea lines in Uganda. Afr Crop Sci J 13 (4): 239-247.

Carvalho M, Muñoz-Amatriaín M, Castro I, Lino-Neto T, Matos M, EgeaCortines M, Rosa E, Close T, Carnide V. 2017. Genetic diversity and structure of Iberian Peninsula cowpeas compared to world-wide cowpea accessions using high density SNP markers. BMC Genom 18 (1): 1-9. DOI: 10.1186/s12864-017-4295-0

Ezeaku IE. 2013. Productivity of Grain Cowpea (Vigna unguiculata (L.) Walp.) as Influenced by Season, Genotype, Insect Pest Managemen and Cropping System in Southeastern Nigeria. [Ph.D Thesis] University of Nigeria, Nsukka, Nigeria.

Frankel R, Galun E. 2012. Pollination Mechanisms, Reproduction and Plant Breeding (Vol. 2). Springer Science \& Business Media.

Henshaw FO. 2008. Varietal differences in physical characteristics and proximate composition of cowpea (Vigna unguiculata). World J Agric Sci 4 (3): 302-306. DOI: 10.1.1.415.1968

Horn L, Shimelis H, Sarsu F, Mw adzingeni L, Laing MD. 2018 Genotype-by-environment interaction for grain yield among novel cow pea (Vigna unguiculata L.) selections derived by gamma irradiation. Crop J 6 (3): 306-313. DOI: 10.1016/j.cj.2017.10.002

Huynh BL, Ehlers JD, Huang BE, Muñoz-Amatriaín M, Lonardi S, Santos JR, Ndeve A, Batieno BJ, Boukar O, Cisse N. 2018. A multi-paren advanced generation inter-cross (MAGIC) population for genetic analysis and improvement of cowpea (Vigna unguiculata L. Walp.). Plant J 93 (6): 1129-1142. DOI: 10.1111/tpj.13827

Lo S, Muñoz-Amatriaín M, Boukar O, Herniter I, Cisse N, Guo YN, Roberts PA, Xu S, Fatokun C, Close TJ. 2018. Identification of QTL controlling domestication-related traits in cowpea (Vigna unguiculata L. Walp). Sci Rep 8 (1): 1-9. DOI: 10.1038/s41598-018-24349-4

Misra VA, Wang Y, Timko MP. 2017. A compendium of transcription factor and transcriptionally active protein coding gene families in cowpea (Vigna unguiculata L.). BMC Genom 18 (1): 1-24. DOI 10.1186/s12864-017-4306-1

Molino L. 2017. Development of advanced mutant lines of barley with higher mineral concentrations through radiation-induced mutagenesis in Peru am. Peruvian J Agron 1 (1): 14-20. DOI: 10.21704/pja.v1i1.1063
Muñoz-Amatriaín M, Mirebrahim $\mathrm{H}, \mathrm{Xu} \mathrm{P}$, Wanamaker SI, Luo M, Alhakami H, Alpert M, Atokple I, Batieno BJ, Boukar O, Bozdag S, Cisse N, Drabo I, Ehlers JD, Farmer A, Fatokun C, Gu YQ, Guo YN, Huynh BL, Jackson SA, Kusi F, Lawley CT, Lucas MR, Ma Y, Timko MP, Wu J, You F, Barkley NA, Roberts PA, Lonardi S, Close TJ. 2017. Genome resources for climate-resilient cowpea, an essential crop for food security. Plant J 89 (5): 1042-1054. DOI: $10.1111 /$ tpj. 13404

Neya FB, Elise S, Koita K, Zagre BM, Sankara P. 2017. Diallel analysis o pod yield and 100 seeds weight in peanut (Arachis hypogaea L.) using Griffing and Hayman methods. J Appl Biosci 116: 19-27. DOI: 10.4314/jab.v116i1.10

Odeseye AO, Amusa NA, Ijagbone IF, Aladele SE, Ogunkanmi LA. 2018. Genotype by environment interactions of twenty accessions of cow pea (Vigna unguiculata (L.) Walp.) across tw o locations in Nigeria. Ann Agr Sci 16 (4): 481-489. DOI: 10.1016/j.aasci.2018.03.001

Purnamasari I, Sobir, Syukur M. 2019. Diversity and inheritance in cowpea (Vigna unguiculata) on protein and yield component characters. Biodiversitas 20 (5): 1294-1298. DOI: 10.13057/biodiv/d200507

Singh B. 2014. Cowpea: The Food Legume of the 21st Century. Crop Science Society of America, Madison, WI, USA.

Sousa MBE, Damasceno-Silva KJ, Rocha MDM, Menezes JJD, Lima LRL. 2018. Genotype by environment interaction in cow pea lines using GGE Biplot method. Rev Caatinga 31 (1): 64-71. DOI: 10.1590/1983-21252018v31n108rc

Vasconcelos EV, De Andrade Fonseca AF, Pedrosa-Harand A, De Andrade Bortoleti KC, Benko-Iseppon AM, Da Costa AF,BrasileiroVidal AC. 2015. Intra- and interchromosomal rearrangements between cowpea [Vigna unguiculata (L.) Walp.] and common bean (Phaseolus vulgaris L.) revealed by BAC-FISH. Chromosome Res 23 (2): 253-266. DOI: 10.1007/s10577-014-9464-2

Wahyudi A, Ariyani D, Ma G, Inaba R, Fukasawa C, Nakano R, Motohashi R. 2018. Functional analyses of lipocalin proteins in tomato. Plant Biotech 35 (4): 303-312. DOI: 10.5511/plantbiotechnology.18.0620a

Wahyudi A, Fukazawa C, Motohashi R. 2020. Function of SITILs and SlCHL under heat and oxidative stresses in tomato. Plant Biotech 37 (3): 335-341. DOI: 10.5511/plantbiotechnology.20.0422a

Yao S, Jiang C, Huang Z, Torres-Jerez I, Chang J, Zhang H, Udvardi M, Liu R,Verdier J. 2016. The Vigna unguiculata gene expression atlas (VuGEA) from de novo assembly and quantification of RNA-seq data provides insights into seed maturation mechanisms. Plant J 88 (2): 318-327. DOI: 10.1111/tpj.13279 